\title{
Evidence of the ongoing trend towards increased longevity
}

Received: 16th November, 2001

\section{Danny Wilding}

joined the pensions consultancy team of Barnett Waddingham in 1991 from Cambridge University. He qualified as a Fellow of the Institute of Actuaries in 1997, and became a partner of Barnett Waddingham in June 1999. Danny takes responsibility for ongoing client service of pension schemes and project work. His work encompasses all areas of consultancy, including research, investment work and pension scheme design as well as actuarial calculation. $\mathrm{He}$ is a speaker for the National Association of Pension Funds trustee training courses. Conference talks around Europe and published articles have included UK pensions reform, company accounting for pension costs and asset-liability modelling. His colleagues Simon Spencer and Chris Watts have assisted Danny in the research of this paper.

\begin{abstract}
This paper considers both the observed increases in longevity over the 20th century as well as potential longevity improvement projections into the future. It describes the work of the Continuous Mortality Investigation Bureau (CMIB) - an organisation which investigates the mortality of those holding pension or life insurance products in the UK. It concludes by considering the consequences of these trends on both defined contribution and defined benefit pension arrangements.
\end{abstract}

Keywords: mortality; mortality improvements; mortality trends; longevity; annuity costs; pension costs

\section{Introduction}

The issue of falling annuity rates in the UK has received considerable attention in recent years. Stories of ever-decreasing pensions abound in the financial pages of the national press; financial and political commentators urge the Government to change the rules that compel people to buy an annuity with their pension fund; and the problems experienced by Equitable Life provide a stark example of the perils that may arise when annuity rates fall below guaranteed levels.

The reasons for the current trend of falling annuity rates are well known and

Danny Wilding

Barnett Waddingham, Bow Bells House, Bread Street, London EC4M 9HN, UK.

Tel: +44 (0)20 7427 7000; Fax: +44 (0)20 7427 7171; E-mail: danny.wilding@ barnett-waddingham.co.uk documented - a low inflation environment and low interest rates, together with continually improving longevity being the main factors. The aim of this paper is to concentrate on one of those factors - longevity — and to provide some background on the trends currently being observed and the long-term implications.

Rates of mortality improved dramatically over the 20th century. This is evidenced in surveys of both the UK population as a whole and the particular experience of UK life offices.

\section{Population data}

To coincide with the national census, every ten years the Government Actuary's Department (GAD) produces a 'life table' based on the mortality experience in England and Wales for a three-year period centred around the census year. These tables are known as the English Life Tables (ELT). Expectations of life at birth evidenced by the ELTs of the last century are set out in Table $1 .^{1}$ 
Table 1

\begin{tabular}{rlll}
\hline ELT & $\begin{array}{l}\text { Census } \\
\text { year }\end{array}$ & $\begin{array}{l}\text { Male life } \\
\text { expectancy }\end{array}$ & $\begin{array}{l}\text { Female life } \\
\text { expectancy }\end{array}$ \\
\hline 7 & 1901 & 45 & 52 \\
8 & 1911 & 52 & 55 \\
9 & 1921 & 56 & 59 \\
10 & 1931 & 59 & 62 \\
11 & 1951 & 66 & 71 \\
12 & 1961 & 68 & 74 \\
13 & 1971 & 69 & 75 \\
14 & 1981 & 71 & 77 \\
15 & 1991 & 73 & 78 \\
\hline
\end{tabular}

From the beginning of the last century to the final decade, the improvement in UK population mortality has been quite startling, with life expectancy increasing by nearly 30 years for both men and women. The greatest improvements were seen in the first half of the century, due notably perhaps to major medical advances during that time, particularly with regard to the control of infectious diseases and the development and increased availability of successful vaccines. While not as spectacular, steady improvements in mortality continued to be made during the latter part of the century.

It will be some time before the results of the 2001 census are analysed and the next ELT is published, but interim tables produced by the GAD based on data for the years 1997 to 1999 suggest that the trend is continuing. Expectations of life at birth calculated from these tables are 75 years for males and 80 years for females. $^{2}$

It is instructive to consider how these figures may affect the cost of state pension provision. In the UK the old age state pension was set up in 1908 as a means tested benefit for men and women over age 70. In 1925 this was changed to provide (in addition to earnings-related pensions funded from employers, employees and the state) a flat rate pension payable from age $65 .^{3}$
Table 2

\begin{tabular}{lll}
\hline $\begin{array}{l}\text { Projection } \\
\text { year }\end{array}$ & $\begin{array}{l}\text { Male life } \\
\text { expectancy }\end{array}$ & $\begin{array}{l}\text { Female life } \\
\text { expectancy }\end{array}$ \\
\hline 2001 & 75 & 80 \\
2011 & 77 & 82 \\
2021 & 79 & 83 \\
\hline
\end{tabular}

Considering that life expectations for men have increased from the high 50 s in 1925 to about 75 now, with no corresponding change in the state pension age, it can be seen why the cost of state pensions has spiralled over the last 75 years. In particular, the remaining life expectancy from age 65 has gone up, for men, from 9.8 years to 14.4 years in this period. The probability of reaching age 65 has also improved dramatically, from less than 50 per cent to over 75 per cent. ${ }^{1}$

The GAD regularly carries out projections to estimate the future population of the UK. These projections include assumptions for future fertility, mortality and migration rates, and the latest such projection was based on an estimate of the resident population of the UK in mid-1998. While it must be stressed that these projections are estimates, it is interesting to note the projection of life expectancy at birth, as shown in Table $2 .^{2}$

\section{The CMIB}

The Continuous Mortality Investigation Bureau (CMIB) is an independent organisation set up under the auspices of the Faculty and Institute of Actuaries. It has been in existence since 1923, and collects and analyses data from UK life offices. Initially, only mortality experience was investigated, but over time further investigations have been added, including the experience of income protection and critical illness policies. Ad hoc analyses 
are also conducted, for example, a pilot investigation into the mortality experience of self-administered pension schemes has recently been carried out. Results from contributing life offices are aggregated and published for the benefit of the insurance industry and the actuarial profession.

From time to time the CMIB also constructs mortality tables from the data it collects. Separate tables are produced for different types of experience. The latest set of tables, based on data relating to the period 1991-94 and designated the ' 92 ' Series, includes separate tables for permanent (whole life and endowment) assurances, temporary assurances, immediate annuitants, retirement annuitants, pensioners in insured group pension schemes, and widows of such pensioners.

These tables more closely reflect the experience of these types of policies than the population life tables and so are used extensively throughout the industry for pricing and reserving purposes. As a general rule, the life expectancy of those with insured pensions annuities tends to be higher than the UK average as a whole, for example, due to the observed correlation between mortality and wealth or social classification.

\section{CMIB data}

The improvements observed in general UK population longevity are also apparent in the insured population data analysed by the CMIB. Table 3 is based on the experience of pensioners in insured group pension schemes, and shows the number of deaths within each CMIB investigation over the last 40 years, compared to each 100 deaths within the 1959-62 investigation. ${ }^{4}$

It can be seen that, for this type of business, overall mortality experience (in terms of the number of deaths
Table 3

\begin{tabular}{lll}
\hline Quadrennium & $\begin{array}{l}\text { Male } \\
\text { deaths }\end{array}$ & $\begin{array}{l}\text { Female } \\
\text { deaths }\end{array}$ \\
\hline $1959-62$ & 100 & 100 \\
$1963-66$ & 99 & 84 \\
$1967-70$ & 95 & 82 \\
$1971-74$ & 94 & 84 \\
$1975-78$ & 92 & 78 \\
$1979-82$ & 82 & 73 \\
$1983-86$ & 74 & 66 \\
$1987-90$ & 66 & 66 \\
$1991-94$ & 60 & 61 \\
$1995-98$ & 54 & 52 \\
\hline
\end{tabular}

experienced) has improved by almost 50 per cent over the last 40 years of the 20 th century.

\section{Projections}

A mortality table is, in effect, a snapshot view of the levels of mortality being experienced at the time the table was constructed. The remaining life of expectancy now of a current 60-year-old will not necessarily be the same as the remaining life expectancy of a current 30 -year-old in 30 years' time. In the case of annuity and pension business, payments are made on the basis of survival and so there are financial risks to the providers of these products if people live longer than expected. It is therefore appropriate to take some account of potential further improvements in future longevity.

The CMIB produces tables for annuitants and pensioners which allow for projections of mortality into the future. This is done by publishing projection factors along with the base mortality tables. Mortality tables for future calendar years can then be obtained by applying the projection factors to the base table. These projections provide two ways of allowing for improving mortality:

- A simplistic approach is to choose a 


\begin{tabular}{|c|c|c|c|c|c|c|c|c|c|c|c|}
\hline Age & 2000 & 2001 & 2002 & 2003 & 2004 & 2005 & 2006 & 2007 & 2008 & 2009 & 2010 \\
\hline 60 & • & & & & & $\bullet$ & & & & & \\
\hline 61 & • & & & & & & $\bullet$ & & & & \\
\hline 62 & • & & & & & & & $\bullet$ & & & \\
\hline 63 & • & & & & & & & & $\bullet$ & & \\
\hline 64 & • & & & & & & & & & $\bullet$ & \\
\hline 65 & • & & & & & - & & & & & $\bullet$ \\
\hline 66 & • & & & & & & - & & & & \\
\hline 67 & • & & & & & & & - & & & \\
\hline 68 & • & & & & & & & & - & & \\
\hline 69 & • & & & & & & & & & - & \\
\hline 70 & • & & & & & & & & & & - \\
\hline 71 & $\bullet$ & & & & & & & & & & \\
\hline 72 & $\bullet$ & & & & & & & & & & \\
\hline
\end{tabular}

Figure 1

single future calendar year (that is expected to reflect the average future experience for the population in question) and use the mortality table projected for that year. For example, using a table projected to 2020 might understate mortality rates initially, but then over time might eventually overstate mortality rates, and may on average be expected to represent a reasonable allowance.

- A more sophisticated approach is to choose a two-way 'Year of Use' table. With this method, a separate set of mortality rates is derived for each individual by using the published projection factors along with the base mortality statistics. In this case the projected mortality rate depends not only on age, but also on when the individual in question reaches that age. Using this method future improvements in mortality are allowed for explicitly for each individual.
These alternative methods can be represented pictorially. Each cell in Figure 1 represents the mortality rate of an individual reaching the age shown in the year shown.

The circles represent a simplified one-way table projected to calendar year 2000. The diamonds and squares represent a more sophisticated two-way table with Year of Use $=2005$, for lives reaching ages 60 and 65 respectively in that year. It can be seen that the one-way table is just one column of figures (with mortality rates determined only by age) but the two-way table is a matrix of figures (with mortality rates determined by both age and year of birth).

The CMIB does not attempt to identify the reasons for mortality improvements, although we can guess that these include increasingly healthy lifestyles, safer workplaces and medical advances. These factors might also go some way to explaining why male 
longevity has caught up slightly on female longevity over the last century. It may be that some of these factors will reach natural limits, and longevity improvements will slow down accordingly. However, there is no evidence that this is yet happening, and it seems prudent to expect the trend to continue.

\section{Defined contribution pension arrangements}

The paper now turns to the effects of improving mortality on pension plans, and in particular annuity costs for defined contribution arrangements. Table 4 shows the theoretical average value (using ELT mortality) of an annuity of $\mathcal{E} 1$ per annum payable to a man from age $60{ }^{1}$

It should be noted that these annuity factors assume a 5 per cent p.a. investment return (as an allowance for post-retirement investment returns in line with UK government bond yields) and pension increases of 3.5 per cent p.a. (as an allowance for future UK price inflation) and in each case differ only in the underlying mortality rate assumption.

Table 4 shows that from 1931 to 1991 improvements in mortality might have resulted in the value of an annuity for a 60 -year-old man increasing by over 20 per cent.

In fact, the life offices that provide annuity policies for pension plans allow for the higher longevity of insured lives compared to the population as a whole (see Table 4). It is therefore also useful to consider how annuity values derived from the most up-to-date UK mortality tables for insured lives (using both the calendar year and year of use tables mentioned above) compare. Table 5 illustrates mortality rates from the most recent ' 92 ' Series of tables that have been projected into the future to allow for further mortality improvements.
Table 4

\begin{tabular}{lll}
\hline ELT & $\begin{array}{l}\text { Census } \\
\text { year }\end{array}$ & $\begin{array}{l}\text { Value of annuity } \\
\text { (per £1 p.a.) }\end{array}$ \\
\hline 10 & 1931 & $£ 12.30$ \\
11 & 1951 & $£ 12.60$ \\
12 & 1961 & $£ 12.80$ \\
13 & 1971 & $£ 13.10$ \\
14 & 1981 & $£ 13.90$ \\
15 & 1991 & $£ 15.00$ \\
\hline
\end{tabular}

Table 5

\begin{tabular}{|c|c|c|}
\hline $\begin{array}{l}\text { Projection } \\
\text { year }\end{array}$ & $\begin{array}{l}\text { Value of } \\
\text { Calendar } \\
\text { year }\end{array}$ & $\begin{array}{l}\text { ty (per } £ 1 \text { p.a.) } \\
\text { Year of use }\end{array}$ \\
\hline 1992 & $£ 18.30$ & $£ 19.50$ \\
\hline 2001 & $£ 19.20$ & $£ 20.20$ \\
\hline 2011 & $£ 20.00$ & $£ 20.90$ \\
\hline 2021 & $£ 20.70$ & $£ 21.30$ \\
\hline 2031 & $£ 21.20$ & $£ 21.70$ \\
\hline 2041 & $£ 21.60$ & $£ 22.00$ \\
\hline
\end{tabular}

Under these levels of mortality the value of the annuity for a man aged 60 (using the same assumptions described above) increases as shown in Table $5 .{ }^{4}$

Comparing the figures in Table 5 with the ELT survey shows that an allowance for the higher insured life longevity increases annuity values by more than 20 per cent, and that values are projected to increase further over a 50-year period into the future by perhaps nearly 20 per cent more. In addition, year of use tables (ie, making an allowance for further post-retirement improvements) might increase the cost by a few per cent more.

It can be seen that underlying pension costs, in line with expectations of life, are increasing steadily and significantly.

\section{Defined benefit pension arrangements}

The effects of mortality improvements within many defined benefit arrangements are only fully realised when 
the last member dies. This differs from a defined contribution arrangement (and some smaller DB arrangements which insure pension payments) where costs are crystallised when annuities are purchased at retirement.

For defined benefit arrangements, the key to adequate long-term funding is that their actuaries need to make appropriate mortality assumptions which will affect funding levels and recommended contribution rates. If improvements in longevity both now and in the future are not fully allowed for, costs of future benefits will be underestimated. Consequently, the contribution rates recommended would be lower than necessary to maintain an adequate funding position.

Such potential underfunding can be a particular problem for a closed or ageing scheme. It may be particularly difficult if the sponsor is now relatively small compared to the size of the scheme, resulting in a gearing effect on the required contribution rate should they need to make good any funding shortfall. Worse still, they may now have no sponsor at all.

It is worth noting that the principal UK regulatory funding basis for DB arrangements, the Minimum Funding Requirement (MFR), does not allow for mortality in line with the most recent survey findings. MFR will typically understate annuity values by around 20 per cent compared to the most recent mortality projections discussed above. The cost of future service will also be underestimated, resulting in a minimum contribution rate under MFR being lower than the current best estimate of future costs. However, it should be mentioned that most actuaries would argue that the financial aspects of the MFR basis are relatively conservative, perhaps compensating for an inadequate longevity allowance currently. Also, it should be remembered that it is only a minimum test - and a test that currently appears to be on its way out.

\section{Conclusions}

Longevity has improved consistently and significantly over the last century. This trend appears to be continuing for now, and it seems reasonable to project further improvements into the future. The consequences for pension costs for both defined contribution and defined benefit arrangements are significant. Annuities will become more and more expensive as long as longevity continues to improve. Despite this, mortality is often considered as being of secondary importance to financial factors. This is an increasingly dangerous view to take, and it is important that mortality rates are given appropriate consideration in assessing long-term pension costs.

\section{References}

1 English Life Tables 1901-1991 produced by the Government Actuary's Department.

2 National Population Projections produced by the Government Actuary's Department (Series PP2 no. 22).

3 HMSO (1991) Options for Equality in State Pension Age, December.

4 The investigations of the Continuous Mortality Investigation Bureau (CMIR 17(1999) and CMIR 19(2000)). 